
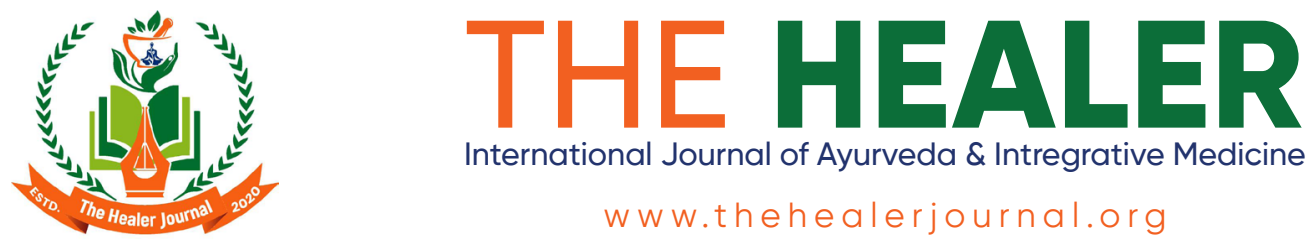

REVIEW ARTICLE

\title{
Role of Kshira in the management of Jalodara (Ascites) - A Brief review \\ ${ }^{1}$ Ekta D. Patel, ${ }^{2}$ Shailly Maurya, ${ }^{3}$ Naoko Kamemori, ${ }^{4}$ T.S. Dudhamal \\ $1,2,3$ PG Scholar ${ }^{4}$ Associate Professor. \\ Dept. of Shalya Tantra, IPGT\&RA, Gujarat Ayurved University, Jamnagar, Indiaa
}

\section{ABSTRACT:}

Jalodara is commone Udarroga in today's area can corelate with ascities. Most common cause of ascites is liver dysfunction due to parenchymal changes which can be correlated with Jalodara. Lolimbaraja boldly stated that only medicines have limited role if Pathya is followed correctly. In Samhitas Kshira (milk) has been considered as a Pathya-Ahara for Jalodara. This review study was aimed to highlight the role of Kshira in the management of the Jalodara. For this the classical texts, other literature related to the subject, research papers and material available on the websites were referred to collect the data. In transudate type of ascites, it creates hypoproteinemia which leads to decrease osmotic pressure intra-vascularly so the accumulation of fluid is occur in peritoneal cavity. Kshira is a best Jivaniya and Rasayan Dravya. By menace of Madhura rasa, Madhur Vipaka \& Shita Virya Kshira passes Srishtavinamutra effect that also act as diuretics and evacuation of collected waste product from the body it turns into detoxification. It also helps to improve the immunity of an individual by its Guna. Kshira is alos called as complete food in Indian continent. Narration of Kshira as a Pathya-ahara in management of Jalodara seems having synergetic effect with the line of treatment as mentioned in classical text.

Keywords: Ayurveda, Ascites, Jalodara, Kshira, Milk

\section{INTRODUCTION}

The liver is a vital organ having a wide range of functions, including detoxification, protein synthesis, and production of enzyms necessary for digestion. As there is currently no way to compensate for the absence of liver function. ${ }^{[1]}$ Ascites is a gastroenterological term for an accumulation of fluid in the peritoneal cavity that exceeds $25 \mathrm{ml} .^{[2]}$ It is one of the most common complication of liver dysfunction

\begin{tabular}{|c|c|}
\hline \multicolumn{2}{|c|}{ Access the article online } \\
\hline Quick Responde Code \\
\hline \\
\hline
\end{tabular}

which cause the remarkable damage to health and lives. End stage of most chronic liver diseases represents as hepatic cirrhosis, which can remain compensated for many years. ${ }^{[3]}$ Decompensated cirrhosis can be characterized by the development of major complications like jaundice, variceal haemorrhage through oesophageal varices, ascites or encephalopathy. ${ }^{[4]}$ Among these complications ascites is the most common. Approximately $50 \%$ of patients with compensated cirrhosis develop ascites over a period of 10

\section{*Corresponding Author:}

\section{Dr. Ekta D. Patel}

PG Scholar. Dept. of Shalya Tantra, IPGT \& RA, Gujarat Ayurved University, Jamnagar, India

Email : ekta2810patel@gmail.com

Submitted: 27.04 .2020

Received: 29.04 .2020

Revised: 12.06 .2020 
years. ${ }^{[5]}$ Approximately $15 \%$ of patients with ascites die within the first 12 months after diagnosis and 44\% with in first 5 years. ${ }^{[6]}$ In Ayurveda, ascites can be correlated with Jalodara, one of the Udara Roga. Among Tridosha, the Prakupita Vata (aggravated Vata) gets accumulated in Udara between Twaka (skin) and Mamsa (muscles tissue) leading to Shotha (swelling); this is being termed as Jalodara can be correlate with ascities. ${ }^{[7]}$ Along with the aggravated Vata, Agni (digestive fire) which is Manda (low) also involved in manifestation of Jalodara. ${ }^{[8]}$ Over eating, very hot, salty, spicy, acidic food, taking dry and impure diet, negligence of the treatment of severe diseases and suppression of natural urges are also the causative factors of Jalodara. Hence, there are multiple factors involved in the causation of Jalodara. In general Ahara (diet) significantly affect one's overall health. According to Acharya Kashyapa there is no medicine like the Ahara on the earth. ${ }^{[9]}$ This indicates the medicinal value of diet. In Ayurveda Ahara, Nidra and Brahmacharya are considered as three sub pillars.. For the management of Jalodara along with medical treatment and surgical procedures, diet restriction also plays an important role for early recovery. Kshira (milk) is described under the Gorasa varga (milk products) and Pey Darvya (liquid food). It is having a property like Jivaniya (increase vitality), Balya (Strengthening), Bhruhania, Rasaniya (increase rejuvenation power). ${ }^{[10]}$ In today's era milk is regarded as a complete food. It is a whitish liquid containing milk proteins, fats, lactose, and various vitamins and minerals. The nutritional value of milk is particularly high due to the balance of the nutrients that compose it [Table-1]. ${ }^{[11]}$ So, here for the purpose of increasing Agni and to maintain nutritional status, Kshira is selected as a Pathya ahara (choice of food) along with Ayurvedic management. Aim \& objectives of the Study was to evaluate the role of Kshira in the management of the Jalodara (Ascites).

\section{METHODS}

Classical texts along with available commentaries, other literature related to the subject, research papers, and information available on websites have been referred and critically analysed with the aim to review of role of Kshira in the management of Jalodara.

\section{RESULT AND DISCUSSION}

In transudate type of ascites, the hydrostatic pressure is increased and there is decrease of the osmotic pressure intravascularly due to hypoproteinaemia which leads to extravascular increase of osmotic pressure along with increased lymphatic pressure. As a result of this, fluid inside the cell comes to the extracellular space thereby increases the collection of fluid in peritoneal cavity. Content of ascites fluid are: RBC (Red blood cell), WBC (White blood cell) from $<100$ to 5000 cell $/ \mathrm{mm}^{3}$, high protein content $>2.5 \mathrm{gm} / \mathrm{dl}^{.}{ }^{[12]}$ In Jalodara Charaka mentioned the use of Nityavirechniya Drvya (routine use of laxatives). Virechana is a process which helps to eliminate Vikrita Doshas (visiated Dosha) through Adhobhagharana hence, both Mutravirechaniya (diuretics) and Malvirechaniya (purgatives) can be consider under this title. For break up the Sanga of all Dosha and remove the excessive fluid, Virechana is necessary. Virechana also decreases abdominal girth and edema by decreasing fluid in the abdominal cavity. ${ }^{[13]}$ Mandagni is the chief causative factor for Jalodara, hence for Agnideepana (increase the digestive fire) diet and water intake is restricted and the patient is kept only on milk diet. It works as Nidana Parivarjana (avoid causative factors). ${ }^{[1]}$ Kshira having properties like Madhura Rasa (sweet taste), Mridu(soft), Slakshana Guna (soft and unctuous nature), Shita Virya (cold potency), Madhura Vipaka and also having Srishtavinamootra property works as a diuretic [15] and purgative. It helps to reduce the extracellular fluid from the cavity. Kshira is a best Jivaniya (increased vitality) and Rasayan Dravya (rejuvenating) which helps to increase the Oja (immunity). In contemporary medicine there is indication of usage of spironolactone and furosemide as a diuretic to decrease the fluid level by inhibiting aldosterone antagonist receptor, but this drug is having side effects like hyponatremia, painful gynecomastia and cause the hypotension. ${ }^{[16]}$ While the milk is having high amount of proteins helps to increase intravascularly protein amount ultimately increase intravascular osmotic pressure. This may happen as fluids is moves from low concentration to high concentration in the body due to osmotic gradient. Due to this, the fluid outside in the extracellular space travels into intracellular space thus the amount of ascites fluid in the peritoneal cavity is decreased. Milk also works as a diuretic which helps in excreting extra fluid from the body and treats hyponatremia. It is having good nutritive value which helps to nourish the whole body of person without intake of normal food which is not digestible due to mandhagni. 


\section{CONCLUSION:}

Only milk as a diet that acts on root of pathology of ascites. So, narration of Kshira as a Pathya-Ahara in Jalodara Chikitsa seems having synergetic effect with the line of treatment as mentioned in classical text.

\section{ABBREVIATIONS: Not Applicable}

ACKNOWLEDGEMENTS: Not Applicable

CONFLICT OF INTEREST: Author declares that there is no conflict of interest.

\section{SOURCE OF SUPPORT: None}

\section{REFERENCES}

1. Physiology of medical college of Georgia: http:en. wikipedia.org/wiki/Liver, Cached - Similar retrieved on 10.8.2010.

2. Pedersen JS, Bendtsen F, Møller S. Management of cirrhotic ascites. Therapeutic advances in chronic disease, May. 2015;6(3):124-37

3. G. Garcia-Tsao and J. K. Lim, "Management and treatment of patients with cirrhosis and portal hypertension: recommendations from the department of veterans affairs, Hepatitis C Resource Center Program and the National Hepatitis C Program," The American Journal of Gastroenterology, vol. 104, no.7,2009, p-1802-1829

4. G. D'Amico, G. Garcia-Tsao, and L. Pagliaro, "Natural history and prognostic indicators of survival in cirrhosis: a systematic review of 118 studies," Journal of Hepatology, vol. 44, no. 1, 2006, p- 217-231

5. N. C. Fisher, J. Hanson, A. Phillips, J. N. Rao, and E. T. Swarbrick, "Mortality from liver disease in the West Midlands, 1993-2000: observational study," British Medical Journal, vol. 325,no.7359, 2002,p-312-313

6. R. Planas, S. Montoliu, B. Ballest ' e et al., "Natural history of patients hospitalized for management of cirrhotic ascites," Clinical Gastroenterology and Hepatology, vol. 4, no. 11, pp. 1385.e1-1394.e1,2006.

7. Acharya YT, editor. Reprint Edition. Ch 13 Ver 11. New Delhi: Chaukhambha Publications; 2016. Charaka Samhita of Charaka, Chikitsa Sthana; p. 491.

8. Acharya YT, editor. Reprint Edition. Ch 13 Ver 10. New Delhi: Chaukhambha Publications; 2016. Charaka Samhita of Charaka, Chikitsa Sthana; p. 491
9. Kashyapa Samhita by Pandit Hemaraja Sharma with the Vidyotini hindi commentary, Chaukhambha Sanskrit Sansthan, Varanasi, Reprint edition, 2015, Khila Sthana $4 / 5, \mathrm{p}-378$.

10. Acharya YT, editor. Charaka samhita of Agnivesha, Sutra Sthana 27/217 Reprint edition, Varanasi: Chaukhamba Orientalia; 2014, p-165.

11. FAO (1998). Organisation des Nations Unies pour l'alimentation et l'agriculture, Le lait et les produits laitiers dans la nutrition humaine, Collection FAO: Alimentation et nutrition. P- 28.

12. Yashpal Munjal, editor. API textbook of medicine, Vol$1,10^{\text {th }}$ edition, American press, $\mathrm{p}-1125$

13. Jadhav DK. An ayurvedic approach in the management of Jalodara (Ascites): A case study. Int J Ayurveda Res. 2016;1: p-90-91

14. Acharya YT, editor. Reprint Edition. Ch 13 Ver 96. New Delhi: Chaukhambha Publications; 2016. Charaka Samhita of Charaka, Chikitsa Sthana; p. 496

15. Acharya YT, editor. Reprint Edition. Ch 1 Ver 108. New Delhi: Chaukhambha Publications; 2016. Charaka Samhita of Charaka, Chikitsa Sthana; p. 22

16. Yashpal Munjal, editor. API textbook of medicine, Vol$1,10^{\text {th }}$ edition, American press, $\mathrm{p}-1125$

\section{How to cite this article:}

Patel ED, Maurya S, Kamemori N, Dudhamal TS, Role of Kshira in Management of Jalodara (Ascites) - Brief review, The Healer Journal, 2020;1(1):1-9.

Table 1. Average composition and distribution of milk proteins

\begin{tabular}{|l|c|c|}
\hline \multicolumn{1}{|c|}{ Milk protein } & $\begin{array}{c}\text { Mean absolute } \\
\text { (g / L) }\end{array}$ & $\begin{array}{c}\text { Averages } \\
\text { (g / L) }\end{array}$ \\
\hline Crude protein & 34 & 100 \\
\hline Protein & 32 & 94 \\
\hline $\begin{array}{l}\text { Insoluble proteins or } \\
\text { whole casein }\end{array}$ & 36 & 82 \\
\hline soluble protein & 6 & 18 \\
\hline$\alpha$-lactoglobulin & 2.7 & 45 \\
\hline B-lactalbumin & 1.5 & 25 \\
\hline Serum albumin & 0.3 & 5 \\
\hline immune globulins & 0.7 & 12 \\
\hline protein peptones & 0.8 & 13 \\
\hline $\begin{array}{l}\text { Non-protein nitrogen } \\
\text { substances }\end{array}$ & 2 & 6 \\
\hline
\end{tabular}

